\title{
ІННОВАЦІЙНІ ПІДХОДИ ДО ПІДГОТОВКИ СУЧАСНОГО ЛІКАРЯ
}

В. М.Запорожан

\author{
Одеський національний медичний університет
}

\section{INNOVATIVE APPROACHES TO MODERN DOCTOR TRAINING}

\author{
V. M. Zaporozhan
}

\author{
Odesa National Medical University
}

\begin{abstract}
Медична галузь, стан якої підлягає реформуванню, потребує лікаря нової формації, який, крім теоретичних, має широкі практичні компетенції, що формуються за допомогою використання сучасних інноваційних технологій. Мова йде про впровадження в практику і розширення мережі університетських клінік, створення симуляційних центрів, електронних бібліотек та ін. - сучасної інфраструктури, яка в повній мірі має забезпечити підготовку лікаря нової якості. В перспективі вищі медичні навчальні заклади мають перетворитися у біомедичні інноваційно-технологічні кластери.
\end{abstract}

Medicine is the subject to reform now. It needs a doctor of a new breed, who, besides of theoretical, has wide practical knowledge forming due to modern innovative technologies. The question is about introduction into practice and expansion of the university clinics system, creation of simulation centers, electronic libraries, etc. - a modern infrastructure, which should completely provide a modern doctor training. In the long view the higher medical educational institutions have to change into the biomedical innovative technology clusters.

Вступ. Нам не раз доводилося чути критику на адресу нашої галузі. І це не дивно. Охорона здоров’я в Україні займає перше місце в рейтингу серед соціальних, політичних та економічних проблем, що існують у державі. 95 \% населення турбують саме питання нашої галузі. I це зрозуміло, бо в нашій країні останні 10-12 років склалася непроста ситуація із станом здоров'я населення, основні показники якого - середня тривалість життя, рівень захворюваності та смертності - далеко не оптимістичні і мають тенденцію до погіршення, особливо це стосується серцево-судинних захворювань, онкології, дитячої та передчасної смертності, за якими наша країна удвічі попереду всієї Європи. Епідемія туберкульозу, збільшення наркоманії, ВІЛ-захворювань, зниження народжуваності на тлі зростання смертності - все це має місце разом із обмеженням доступності для більшості населення до безоплатної медицини, погіршенням якості медичних послуг, недостатком медичних кадрів.

Але при цьому в Україні кількість установ охорони здоров'я удвічі більша, ніж у країнах $С$, за кількістю ліжко-місць ми в півтора-два рази випереджаємо Європу - у нас 91 ліжко-місце на 10 тисяч населення, в $\mathrm{CC}-55$.

\footnotetext{
(c) B. М. Запорожан
}

Усе це разом із хронічним недофінансуванням визначило економічну неефективність і громіздкість нашої системи охорони здоров'я, що призвело до іiі зубожіння і занепаду.

Найбільше нещастя для лікаря, коли він знає, що треба робити, вміє це робити, але йому нема чим це робити. Найбільша трагедія для держави, коли через відсутність інструментарію або ліків гинуть люди. Але найбільше розчарування, звичайно, у пацієнтів, яким нема де отримати кваліфіковану допомогу.

Реалізація медичної реформи в Україні розпочалась, але потребує істотних коректив. I насамперед це стосується нових підходів до системи підготовки медичних кадрів, тому що лікар є головною дієвою особою, від якості роботи якого залежить стан медицини в країні. Тому, за великим рахунком, майбутне здоров'я нації формується в університетських аудиторіях.

Основна частина. Ті стандарти, за якими зараз працюють медичні ВНЗ країни, розроблені ще у 2003 році, вони не віддзеркалюють повною мірою сучасних вимог до підготовки лікаря, тому потребують перегляду й оновлення. І акцент тут має бути зроблений на формуванні у студентів широкого кола компетенцій та міцно закріплених практичних навичок без ризику заподіяння шкоди пацієнту, здатності 
швидко приймати рішення та бездоганно виконувати більшість маніпуляцій і втручань, особливо при невідкладних станах.

За останнє десятиліття не тільки світова, але й вітчизняна медична освіта, отримали нові механізми і технології, впровадження яких дозволяє підняти підготовку лікаря на якісно новий інноваційний рівень.

Специфіка медичної освіти передбачає тісну взаємодію з клініками і підготовку лікаря біля ліжка хворого. Це - аксіома. Клінічні кафедри більшості вищих медичних навчальних закладів України розташовані на базі міських лікувальних закладів. Час продемонстрував недолугість такої практики.

По-перше, матеріальний стан цих закладів охорони здоров' я не відповідає вимогам навчальних баз лікаря завтрашнього дня неможливо готувати на обладнанні дня вчорашнього. По-друге, сучасний лікар має володіти інноваційними технологіями діагностики і лікування, технікою ендоскопічних, малоінвазивних, реконструктивно-пластичних втручань тощо [1]. А для цього студент повинен вчитися у найкращих хірургів, які виконують високотехнологічні операції у відповідно оснащених операційних, до яких студент мав би доступ. Саме тому у країнах Свропи, Америки, навіть у Росії при вищих медичних навчальних закладах існують університетські клініки. В Україні також є чималий позитивний досвід створення і роботи таких клінік. Як приклад - багатопрофільна університетська клініка Одеського національного медичного університету. Десятирічний досвід її роботи переконливо довів доцільність основної ідеї університетської клініки - клінічне впровадження найновіших технологій і інтелектуальних досягнень, які відпрацьовуються і впроваджуються метрами лікувальної професії одночасно з навчальним процесом. У клініці унікально поєднуються додипломна і післядипломна підготовка лікаря, наукова робота і надання висококваліфікованої медичної допомоги. При цьому навчання й лікувально-діагностична робота здійснюються з використанням найсучаснішої медичної апаратури і новітніх медичних технологій iз залученням висококваліфікованих фахівців різних профілів. Нині університетські клініки $\epsilon$ ще в кількох медичних університетах країни. Вони мають різні потужність, рівень оснащення та модель функціонування, але всі є безапеляційним доказом необхідності створення власних клінік у кожному медичному університеті.

Однак цей процес просувається в нашій країні дуже повільно i, як кажуть, швидше всупереч, ніж завдяки. Тому що наявність клініки у медичному універ- ситеті законодавчо не підтверджена, тож не є обов'язковою.

Ще Конфуцій сказав: “Я почув - і забув, я побачивi запам' ятав, я зробив - i зрозумів". Ця формула якнайкраще ілюструє необхідність поліпшення практичної складової у системі підготовки лікаря. Не випадково у 2005 році замість теоретичних державних іспитів введено комплексний практично орієнтований державний випускний іспит, де молодий лікар має продемонструвати не тільки теоретичні знання, а й роботу з реальним пацієнтом, конкретні практичні навички. Але це лише півкроку до мети - якісної підготовки лікаря сучасного рівня.

Тому що класична система медичної освіти не здатна повною мірою розв’ язати проблему якісної практичної підготовки фахівця. Серед головних перешкод - відсутність безперервного зворотного зв'язку між студентом, курсантом і педагогом, а також можливостей щодо практичної ілюстрації всього спектра різноманітних клінічних ситуацій. Існують і моральноетичні та законодавчі обмеження контактів між пацієнтами і студентами-медиками чи курсантами.

В усьому світі ці завдання розв'язуються за допомогою симуляційних технологій і студента не допускають до спілкування з пацієнтом, поки він не складе заліки з практичних навичок. Особливо це стосується хірургіï, реанімації та інших дисциплін, де від якості та швидкості надання медичної допомоги залежить життя пацієнта. Застосування широкого арсеналу тренажерів, комп'ютерне моделювання клінічних ситуацій у динаміці їх розвитку-все це відкриває нові можливості для практичної підготовки студентів та підвищення кваліфікації лікарів і медичних сестер, створює реальні умови для контролю викладачем якості знань і навичок студента [2]. Без інноваційних методів навчання підготувати сучасного лікаря неможливо.

Нещодавно Одеський національний медичний університет виграв грант Свросоюзу на реалізацію проекту “Chronex", на базі якого було створено Навчально-інноваційний центр практичної підготовки лікарів, оснащений обладнанням із першого до сьомого рівня реальності. Це обладнання дозволяє навчати студентів і медичний персонал практично в усіх сферах медичної діяльності, використовуючи сучасні методи та методики, в тому числі моделювання клінічних ситуацій різних рівнів складності, моделювання віртуальної реальності, “стандартизований пацієнт”, систему психологічного консалтингу та менеджменту, а також гібридну симуляцію [3].

Центр координує свою роботу з провідними центрами симуляційних технологій світу і коли запрацює на 
повну потужність - може стати базовим для модернізації перепідготовки лікарів із інших регіонів України.

Інновації потребує також і теоретична підготовка лікарів. У наш час теоретично “підкувати" висококваліфікованого лікаря означає забезпечити йому доступ до світової наукової та будь-якої інформації іншої перспективи не існує. Тому одним із перших завдань Концепції розвитку нашого університету було створення найсучаснішої електронної бібліотеки [4]. Такі бібліотеки функціонують і в багатьох інших університетах. Але, знову ж таки, і в цьому питанні вітчизняне законодавство відстає від життя. Потрібно створити Сдину галузеву освітню інформаційну систему, об'єднавши всі інформаційні ресурси університетів країни, щоб нею могли користуватися не лише студенти, а всі охочі фахівці галузі. Це вже не просто бажання, а необхідність. Якби не одне "але" - не зрозуміло, як це узгоджуватиметься із Законом України про авторське право. Прийнятий в 90-ті роки минулого століття, він не передбачає створення електронних копій книжок та інших документів без згоди автора. Мова йде про виплату авторських гонорарів. Наскільки реально це для університетів? Вважаю, потрібно внести зміни до Закону, які б розмежували цілі створення електронних копій і дали б можливість розвиватися електронним бібліотекам.

\section{Література}

1. Запорожан В. М. Сучасна організація навчального процесу / В. М. Запорожан, Н. М. Рожковська, А. Г. Волянська // Сучасні технології вищої освіти : тези доп. VI Всеукр. наук.-метод. конф.-Одеса:ОДАХ, 2010.-239 с.

2. Симуляционное обучение в медицине / под ред. А. А. Свистунова.-М. : Издат. Первого МГМУ им. И. М. Сеченова, 2013. $-288 \mathrm{c}$.

3. Горшков М. Д. Подразделение симуляционно-аттестационных центров на три уровня / М. Д. Горшков // Виртуальные технологии в медицине. -2013. - № 2(10). C. 24-27.
Висновки. Вимоги, які стоять перед вищими медичними навчальними закладами щодо підготовки якісно нового фахівця, потребують змін і в самому виші.

Сучасний вищий медичний навчальний заклад це інфраструктура (навчальні корпуси, клініки, лабораторії, центри, бібліотеки тощо), складові якої взаємопов’язані спільними завданнями - здійснювати навчальну, наукову і лікувальну діяльність. У подальшому він має розвиватися як біометричний інноваційно-технологічний кластер $[5,6]$. Це один нерозривний комплекс, до складу якого мають долучитись, крім університету, найпотужніші регіональні лікувальні установи, академічні науково-дослідні інститути, підприємства, що виробляють медичну продукцію і ліки.

Невід'ємною рисою кластера стане впровадження сучасних технологій в усі сфери діяльності. Це дасть можливість медичним університетам йти в ногу з модернізацією медичної сфери країни, наблизить розробки та новітні технології до практичного впровадження, скоротить шлях від суто теоретичної підготовки фахівця до надання йому міцних практичних навичок і формування розвиненого клінічного мислення. Тобто це дасть можливість отримати якісно іншого лікаря, який буде готовий працювати в умовах оновленої галузі.

4. Організація роботи інформаційно-технологічних систем бібліотеки вищого медичного (фармацевтичного) навчального закладу / [О. М. Бруй, Н. В. Гаріна, Т. В. Карпенко та ін.]. -О. : Одеський медуніверситет, 2014. -32 с.

5. Гордеев Д. Технологические кластеры и их роль в экономике /Д. Гордеев // Вісник економічної науки України. 2011.-№2.-С. 213-215.

6. Жаворонков Е. П. Кластерная стратегия в развитии медицинских организаций / Е. П. Жаворонков // Медицина и образование в Сибири. - 2013. - № 1. - Электронный научный журнал. 